\title{
Algoritma Sequential Search Dalam Kamus Bahasa Inawatan Berbasis Android
}

\author{
Kristia Yuliawan \\ Jurusan Teknik Informatika Universitas Papua \\ k.yuliawan@unipa.ac.id
}

\begin{abstract}
Abstrak - Setiap tahun penutur bahasa inawatan mengalami penurunan. Pengunaan bahasa nasional yaitu bahasa indonesia dalam bahasa komunikasi yang berkembang dengan pesat dalam bahasa komunikasi sehari-hari memberikan dampak yang signifikan terhadap penutur bahasa inawatan yang tidak antusias dalam mengajarkan bahasa inawatan kepada keturunannya. Kurangnya minat generasi selanjutnya dalam melestarikan bahasa inawatan yang disebabkan oleh faktor lingkungan yang tidak mendukung pelestarian bahasa inawatan menyebabkan jumlah penutur bahasa inawatan semakin turun drastis setiap tahun. Untuk mengatasi permasalahan tersebut, diperlukan alternatif dalam meningkatkan kemampuan penguasaan bahasa inawatan yaitu dengan membuat sebuah aplikasi kamus bahasa inawatan. Dalam pembuatan aplikasi ini digunakan algoritma sequential search hal ini disebabkan karena dengan metode ini digunakan dengan sederhana sehingga pencarian datanya lebih cepat sehingga waktu yang dibutuhkan lebih singkat sedangkan metode dalam pengujiannya mengunakan metode black box. Adapun mamfaat dengan adanya aplikasi kamus bahasa inawatan mempermudah masyarakat dalam mempelajari bahasa inawatan dengan efektif dan efesien.
\end{abstract}

Kata kunci : Bahasa Inawatan, algoritma sequencial search, kamus bahasa, metode black box, bahasa komunikasi.

\section{PENDAhUluan}

Balai bahasa di papua memberikan informasi tentang jumlah bahasa yang terdapat di dua provinsi yaitu papua dan papua barat yang berjumlah kurang lebih 414 bahasa dalam kurun waktu 2018 sampai dengan 2019. Salah satu bahasa yang berada di papua barat adalah bahasa inawatan. Bahasa inawatan dituturkan sebagai bahasa keseharian dari kampung mate, distrik Inawatan Kabupaten sorong selatan provinsi papua barat. Salah satu kelompok sosial ini berdiam di daerah kepala burung pulau papua, berdasarkan sumber resmi penutur bahasa inawatan berjumlah kurang lebih 1.100 orang. Suku inawatan adalah salah satu dari sembilan suku yang tergabung dalam sautu kelompok dalam suatu kelompok suku bangsa besar yaitu suku bangsa Teminabuan. Masing-masing suku salam suku bangsa tenimabuanini memiliki bahasa tersendiri.

Setiap tahun penutur bahasa inawatan mengalami penurunan sebagai bahasa komunikasi sehari-hari. Pengunaan bahasa nasional yaitu bahasa indonesia dalam bahasa komunikasi yang berkembang dengan pesat dalam bahasa komunikasi seharihari menyebabkan memberikan dampak yang signifikan terhadap penutur bahasa inawatan yang tidak antusias dalam mengajarkan bahasa inawatan kepada keturunannya. Kurangnya minat generasi selanjutnya dalam melesatarikan bahasa inawatan yang disebabkan oleh faktor lingkungan yang tidak mendukung pelestarian bahasa inawatan menyebabkan jumlah penutur bahasa inawatan semakin turun drastis setiap tahun.

Dengan adanya perkembangan teknologi handphone yang semakin maju memudahkan kita dalam mempelajari bahasa. Untuk melestarikan bahasa inawatan sebagai bagian kekayaan bahasa di tanah papua maka perlu suatu aplikasi kamus bahasa inawatan. Kosakata dari bahasa indonesia yang diterjemahkan menjadi bahasa inawatan dapat mempermudah bagi setiap orang dalam mempelajari bahasa inawatan.

\section{METODE PENELITIAN}

A. Metode Pengumpulan Data

Dalam melaksanakan penelitian ini, metode pengumpulan dilaksanakan dengan studi pustaka yaitu dengan mencapatkan informasi yang relevan dengan masalah yang diteliti dengan memngumpulkan dari sumber-sumber pustaka seperti buku, jurnal penelitian dan internet.
B. Metode Pengembangan Sistem

Metode pengembangan sistem yang digunakan dalam peneitian ini adalah metode incremental. Metode ini dipecahkan menjadi beberapa bagian, adapun beberapa bagian tersebut adalah sebagai berikut :

1. Requirement

Requirment adalah proses tahapan awal yang dilakukan dengan menentukan kebutuhan atau analisis kebutuhan.

2. Specification

Specification adalah proses spesifikasi dimana menggunakan analisis kebutuhan sebagai acuannya.

3. Architecture Design

Architecture Design adalah tahap selanjutnya, perancangan software yang terbuka agar dapat diterapkan sistem pembangunan per-bagian pada tahapan selanjutnya.

4. Code

Code setelah melakukan proses desain selanjutnya ada pengkodean.

5. Test

Test merupakan tahap pengujian dalam model ini

\section{HASIL DAN PEMBAHASAN}

1. Requirement

Dalam melaksanakan proses requirement perlu diketahui kebutuhan atau keinginan dalam pembuatan sistem. Metode yang digunakan dalam pembuatan aplikasi kamus adalah mengunakan metode sequensial searh. Dengan metode sequensial search digunakan dalam pencarian kosakata dari urutan paling depan ke belakang berdasarkan kata kunci. Kelebihan dari metode sequential search adalah mudah digunakan karena mengunakan algoritma sederhana sehingga pencarian datanya lebih cepat sehingga waktu yang dibutuhkan lebih singkat.

Dengan kelebihan yang dimiliki metode sequensial search maka proses pencarian kata dalam kamus inawatan dapat cepat ditampilkan kepada pengguna. Metode sequntial search digunakan dengan membandingkan satu kata dengan kata lainnya dalam basis data kamus inawatan, pencarian kata ini dilaksanakan dengan proses pencarian dari urutan pertama kata dalam basis data kamus sampai dengan kata urutan terakhir. Jika kata ditemukan maka kata yang dicari ditemukan sedangkan apabila kata tidak ditemukan maka kata tersebut tidak terdapat dalam basis data aplikasi kamus inawatan. 


\section{Specification}

Untuk merancang dan membuat aplikasi kamus inawatan maka dibutuhkan perangkat keras dan perangkat lunak sebagai berikut :

A. Perangkat keras

Perangkat keras yang digunakan adalah laptop dan $H P$ smartphone yang digunakan adalah sebagai berikut :

Laptop yang digunakan dengan spesifikasi :

1) Processor : Intel ${ }^{\circledR}$ Core $^{\mathrm{TM}}$ i3 $5005 \mathrm{U}$ Processor

2) Operating System : Windows 10

3) Memory : 4 DDR3L $1600 \mathrm{MHz}$ SDRAM, up to $8 \mathrm{G}$

4) Display : 15.6" 16:9 HD (1366x768)

5) Graphic : Integrated Intel® HD Graphics 4400

6) Storage : 1TB HDD

7) Optical Drive : Super-Multi DVD (On selected models)

8) Card Reader : 3 -in-1 card reader ( SD/ SDHC/ SDXC)

9) Camera : VGA Web Camera

10) Networking : Integrated $802.11 \mathrm{~b} / \mathrm{g} / \mathrm{n}$ or $802.11 \mathrm{ac}$

11) Built-in Bluetooth ${ }^{\mathrm{TM}}$ V4.0 (Optional) : 10/100 Base T

HP smartphone yang digunakan dengan spesifikasi :

1) Chipset: Mediatek MT6765 Helio P35 (12nm)

2) RAM: $3 \mathrm{~GB}$

3) Memori internal: $32 \mathrm{~GB}$

4) Ukuran HP: $164.41 \times 76.32 \times 8.41 \mathrm{~mm}$

5) Ukuran layar: 6.5 inci, $720 \times 1600$ pixels

6) Kamera depan: 8MP

7) Kamera belakang: Dual camera, $13 \mathrm{MP}+2 \mathrm{MP}$

8) Baterai: Li-Po $5000 \mathrm{mAh}$

B. Perangkat lunak

9) Sistem Operasi Windows 1064 bit

10) MIT App Inventor Online

11) Database Firebase

12) Mozilla Firefox 85.0 .264 bit

3. Architecture Design

A. Use Case Diagram

Use Case Diagram mengambarkan hubungan aktor dengan sistem. Adapun use case diagram pada aplikasi kamus bahasa inawatan dapat digambarkan sebagai berikut :

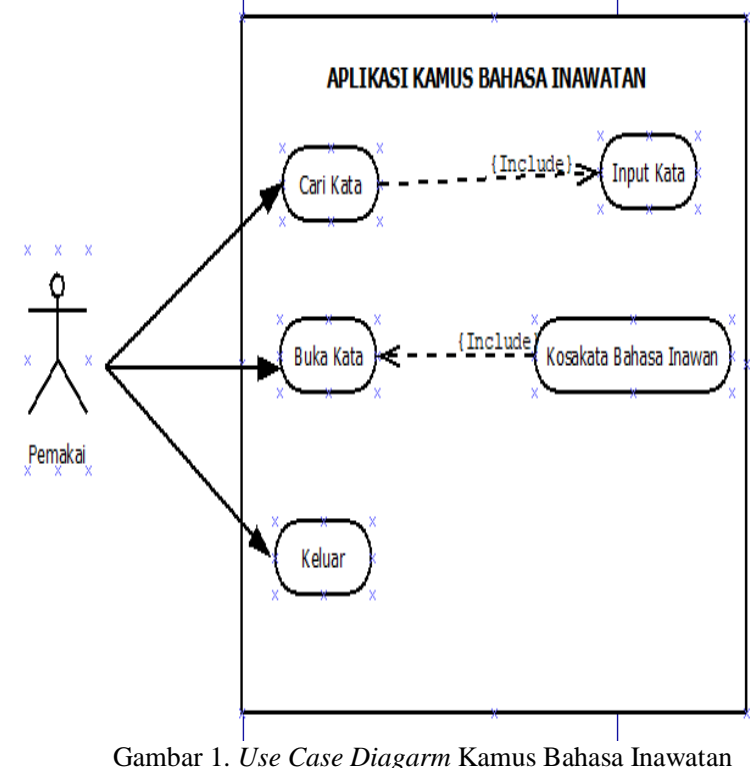

B. Activity Diagram

Activity Diagram merupakan rancangan aliran aktivitas aktor dalam sebuah sistem. Adapun activity diagram pada pemakai terhadap aplikasi kamus bahasa inawatan adalah sebagai berikut :

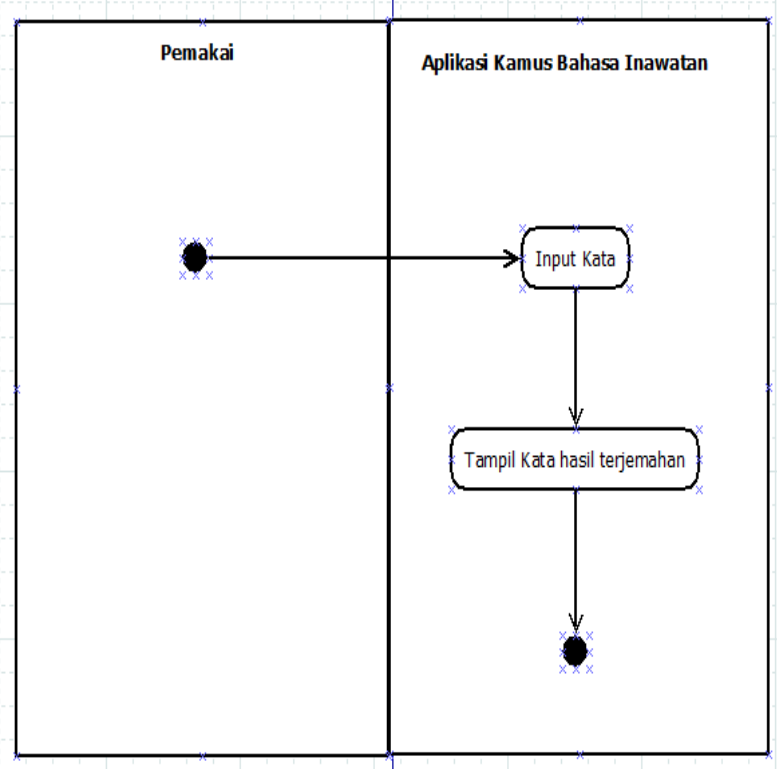

Gambar 2. Activity Diagarm Input Kata

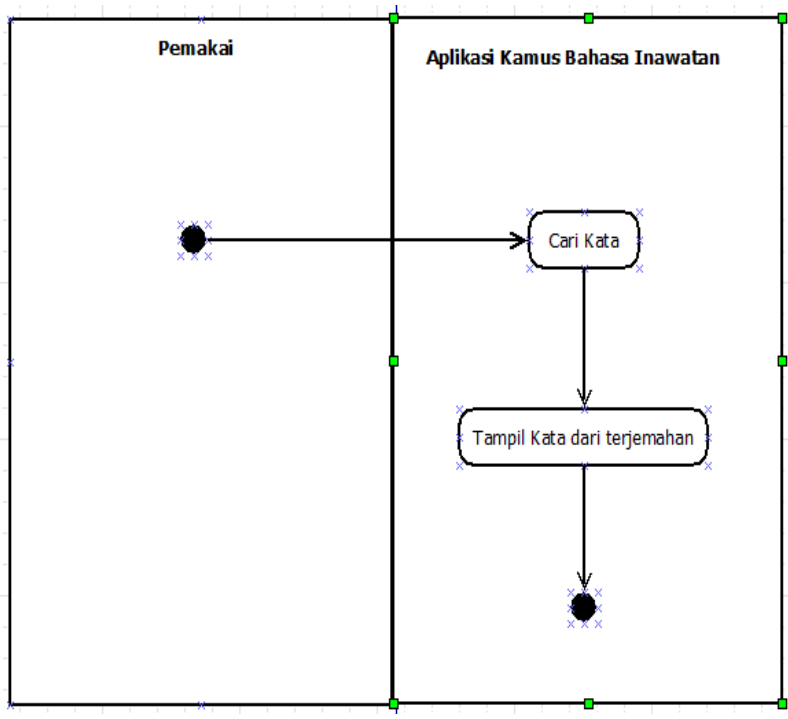

Gambar 3. Activity Diagarm Cari Kata

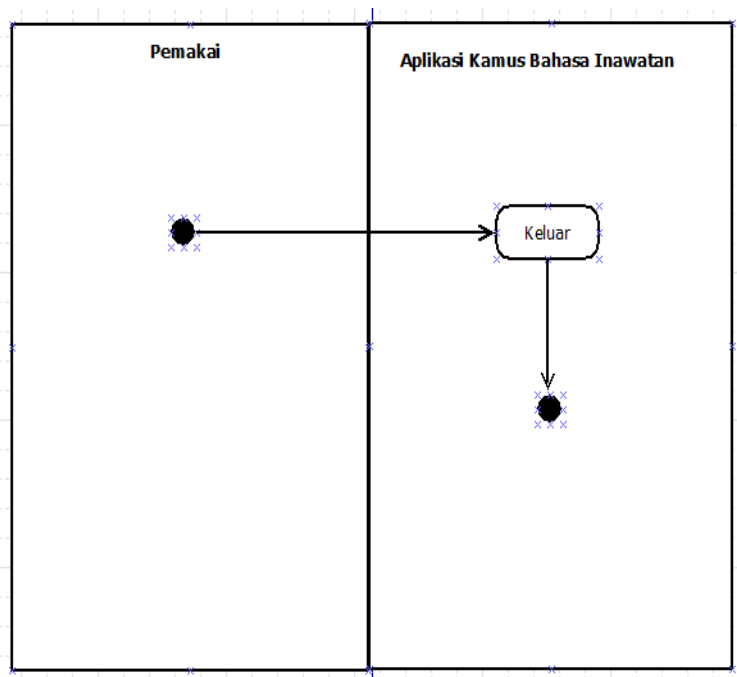

Gambar 4. Activity Diagarm keluar dari sistem 


\section{Code}

Program yang digunakan dalam membuat aplikasi kamus bahasa inawatan adalah aplikasi app inventor. App inventor adalah aplikasi yang dikembangkan oleh perusahaan google dan dimana pengelolaanya dibawah Massachusetts Intitute of Technologi. Pemrograman app inventor mempermudah dalam membuat program berbasis android tanpa harus mengenal syntax program. Adapun tampilan dari hasil program aplikasi kamus bahasa inawatan adalah sebagai berikut :

\section{A. Tampilan Menu awal}

Tampilan awal pada aplikasi kamus bahasa inawatan bisa dilihat pada gambar dibawah ini :

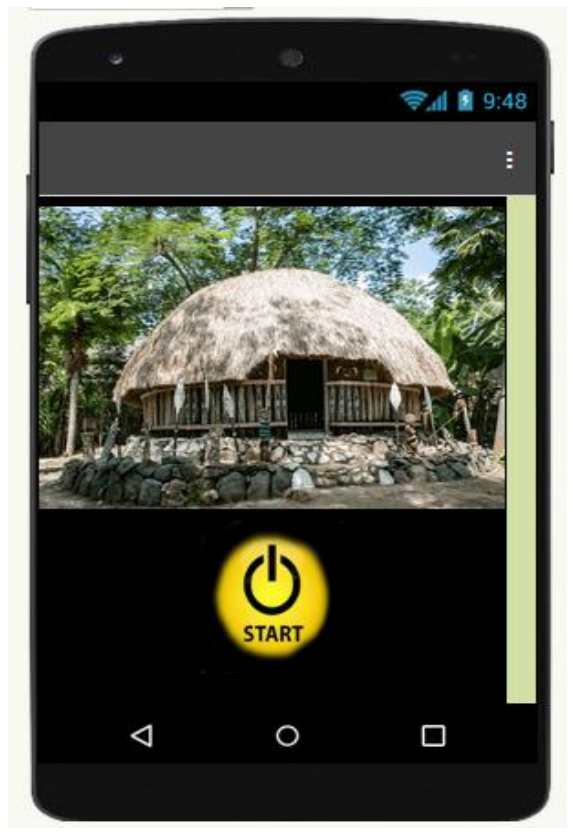

Gambar 5. Tampilan awal aplikasi

B. Tampilan Input Kata

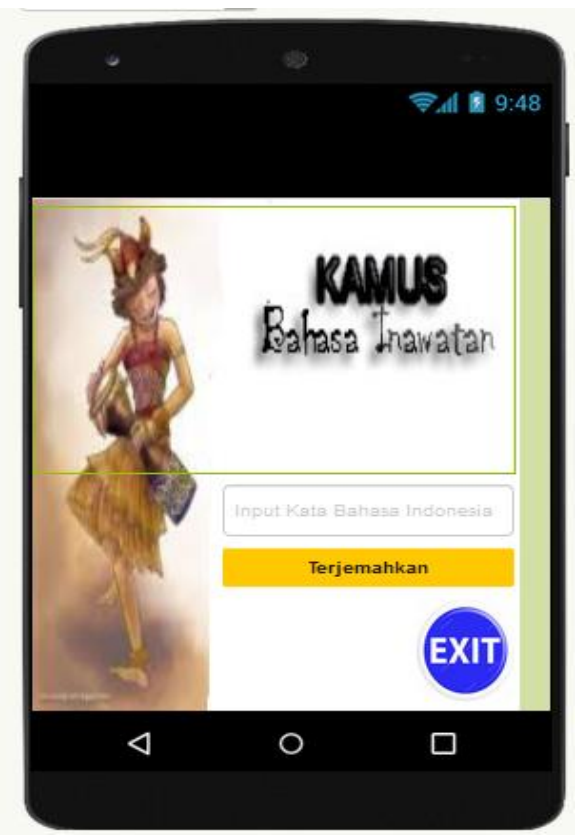

Gambar 6. Tampilan Input Kata
5. Test

Untuk test atau pengujian maka untuk test aplikasi kamus bahasa inawatan mengunakan metode black box.metode black box adalah metode test yang hanya menitikberatkan pada pengujian yang berdasarkan hasil aplikasi beserta funsinya. Adapun hasil pengujian black box aplikasi kamus bahasa inawatan dapat dilihat pada tabel sebagai berikut :

\begin{tabular}{|l|l|l|l|}
\multicolumn{5}{|c|}{ Tabel 1 : Test dengan metode black box } \\
\hline $\begin{array}{l}\text { Aktivitas Pengujian } \\
\text { Masuk ke halaman } \\
\text { awal }\end{array}$ & $\begin{array}{l}\text { Terhubung ke halaman } \\
\text { awal }\end{array}$ & $\begin{array}{l}\text { Berada di halaman } \\
\text { awal }\end{array}$ & Berhasil \\
\hline Klik tombol "start" & $\begin{array}{l}\text { Muncul halaman input kata } \\
\text { dalam kamus }\end{array}$ & $\begin{array}{l}\text { Tombol "start" } \\
\text { berfungsi dengan } \\
\text { baik }\end{array}$ & Berhasil \\
\hline $\begin{array}{l}\text { Masuk ke halaman } \\
\text { awal }\end{array}$ & $\begin{array}{l}\text { Terhubung ke halaman } \\
\text { kamusl }\end{array}$ & $\begin{array}{l}\text { Berada di halaman } \\
\text { kamus }\end{array}$ & Berhasill \\
\hline Klik tombol & Muncul arti kata dalam & $\begin{array}{l}\text { Tombol "terjemahan" } \\
\text { berfungsi dengan } \\
\text { beik }\end{array}$ & Berhasil \\
\hline kerjemahan" & kamus & $\begin{array}{l}\text { Tombol "Exif" } \\
\text { berfungsi dengan } \\
\text { baik }\end{array}$ & Berhasil \\
\hline Klik tombol "Exit" & Keluar dari aplikasi & & \\
\hline
\end{tabular}

\section{KESIMPULAN}

Dari metode perangkat lunak yang mengunakan metode icremental yaitu dari requirement, spesification, architetectur design, code dan test maka di dapatkan kesimpulan aplikasi kamus bahasa inawatan telah berjalan dengan baik sehingga dapat digunakan oleh masyarakat dalam mempelajari bahasa inawatan dengan efektif dan efesien.

\section{DAFTAR PUSTAKA}

[1] Ahmad Nuril Arrasid, Muh. Sadly Said (2016), Aplikasi kamus bahasa daerah tolaki berbasis android, Jurnal Sistem Informasi dan Teknik Komputer , 1(1), 62-68.

[2] Anisya Sonita, Mayang Sari (2018), Implementasi algoritma sequencial search untuk pencarian nomor surat pada sistem arsip elektronik, Jurnal Pseucode, 5(1), 1-9.

[3] Imadudin Aziz, Hani Harafani (2016), Aplikasi kamus bahasa betawi berbasis android mengunakan metode sequencial search, Jurnal Penelitian Ilmu Komputer, System Embedded \& Logic, 4(1), 27-35.

[4] Lady O. Kasema, Steven R. Sentinuwo, Alwin M. Sambul (2018), Aplikasi kamus bahasa daerah pasan berbasis android, Jurnal Teknik Informatika 13(2), 1-6.

[5] Suhartini, Muchlis, Rizky Puji Lestari (2018), Implementation of sequencial search method on android based jakabaring dictionary, Transformatika Journal, 16(1), 74-83. 